\title{
Pharmacokinetics of antimicrobials in obese children
}

\author{
Mario R Sampson 1,2, PharmD; Michael Cohen-Wolkowiez 1,3, MD, PhD; Professor Daniel Kelly Benjamin J1,3, \\ MD, MPH, PhD; Edmund V Capparellit, PharmD; Kevin M Watt ${ }^{1,3}, M D$
}

\begin{abstract}
Introduction: Childhood obesity is common and results in substantial morbidity. The most commonly prescribed drugs in obese children are antibiotics. However, physiological changes associated with childhood obesity can alter antibiotic pharmacokinetics and optimal body size measures to guide dosing in this population are ill defined. This combination can result in therapeutic failures or drug-related toxicities. This review summarizes pharmacokinetic information for antibiotics in obese children and implications for dosing.

Methods: We conducted a comprehensive literature search of PubMed, EMBASE, and International Pharmaceutical Abstracts to identify pharmacokinetic studies of antimicrobial agents in obese children. We included the following search terms: obesity, pharmacokinetics, pharmacodynamics, drug toxicity, dosing, anti-infective agents, antiviral agents, and antifungal agents.

Results: We identified four pharmacokinetic studies of antibiotics in obese children: one for cefazolin and tobramycin, one for gentamicin, and two for vancomycin. Only the cefazolin/tobramycin trial was prospective. The drugs studied differ in their tissue and body water distribution characteristics. Two of the studies (tobramycin and gentamicin) reported pharmacokinetic differences and required dosing modifications in obese children.

Discussion: The lack of pharmacokinetic studies in obese children is pronounced. The scarcity of pharmacokinetic data limits the ability to predict drug disposition using drug physicochemical properties and impedes a rational approach to selection of appropriate body size measures for dosing. Given this knowledge gap, additional trials in obese children are urgently needed and is a public health concern.

Conclusion: Pharmacokinetic studies of antimicrobials in obese children are desperately needed to guide dosing and avoid therapeutic failures or unwanted toxicities.
\end{abstract}

Keywords: Antimicrobial agents, obesity, paediatrics, pharmacokinetics

\section{Introduction}

The World Health Organization (WHO) defines obesity as body mass index (BMI)-for-age measurement $>3$ standard deviations above the reference median [1, 2]. The United States Centers for Disease Control defines obesity as BMI-for-age-and-sex $>95$ th percentile [3]. In the US and Europe, the prevalence of childhood obesity is $16.9 \%$ and $4-6 \%[4,5]$. Childhood obesity is common and associated with significant morbidity and mortality. Obese children are more likely to die prematurely or develop weightrelated illnesses compared with their normal-weight peers [6, 7].

Obesity results in numerous changes to physiology and body composition that may affect drug disposition, see Table 1 [8-21]. Pharmacokinetics (PK) can be altered in obesity through changes to volume of distribution (V) and clearance (CL), the primary determinants of drug dosing. Changes in body composition (increased fat mass per $\mathrm{kg}$ or per $\mathrm{m}^{2}$ ) in obese children may result in the need for dose adjustments using different measures of body size such as total/actual body weight (TBW), ideal body weight (IBW), adjusted body weight (ABW), or lean body weight (LBW). Poor outcomes for obese patients with certain life-threatening conditions may result from suboptimal dosing strategies; for example, suboptimal dosing of obese adult oncology patients and obese children following cardiopulmonary resuscitation may be responsible for underdosing and reduced survival, respectively $[22,23]$.

Antibiotics comprise the class of medications most commonly prescribed in children [24]. Optimal dosing of these drugs in obese children is critical because such patients may be more susceptible to infection [25], and inappropriate dosing can lead to therapeutic failure, antibiotic resistance, and drug-related toxicity. This article will review the current PK information available for antibiotics in obese children and implications for dosing.

\section{Methods}

We searched PubMed, EMBASE, and International Pharmaceutical Abstracts databases for PK studies of antimicrobial agents in obese children (all years). We used combined search terms including obesity, pharmacokinetics, pharmacodynamics, drug toxicity, dosing, anti-infective agents, antiviral agents, and antifungal agents. We limited the search to children $<18$ years of age. We included studies if they provided PK data in obese children receiving an antimicrobial agent.

This review discusses the following body size descriptors: TBW $(\mathrm{kg})=$ measured body weight; IBW $(\mathrm{kg})=2.3 \mathrm{~kg} \times$ (height (in) -60$)+a$, where $\mathrm{a}=45.5 \mathrm{~kg}$ for women and $50 \mathrm{~kg}$ for men; BMI $\left(\mathrm{kg} / \mathrm{m}^{2}\right)=$ TBW $/$ height $^{2}$; LBW $(\mathrm{kg})=\mathrm{b} \times$ TBW $-(\mathrm{c} \times$ BMI $\times$ TBW), where $b=1.1$ for males and 1.07 for females, and $\mathrm{C}=0.0128$ for males and 0.0148 for females; $\mathrm{ABW}(\mathrm{kg})=\mathrm{IBW}+$ $0.4 \times($ TBW-IBW) [26-29]; and dosing weight $=$ the weight used by the pharmacy to dispense the drug.

\section{Results}

The PubMed search strategy identified 90 articles, among which four studies of antimicrobial PK in obese children met the inclusion criteria. Searches of EMBASE and International Pharmaceutical Abstracts did not yield additional peer-reviewed

Author for correspondence: Michael Cohen-Wolkowiez, MD, PhD, Duke Clinical Research Institute, PO Box 3499, Durham, NC 27710, USA

Submitted: 23 April 2013; Revised: 24 May 2013; Accepted: 27 May 2013; Published online first: 10 June 2013 


\begin{tabular}{|l|l|l|}
\hline \multicolumn{3}{|c|}{ Table 1: Selected physiological and body composition changes } \\
reported in obese adults and children [8-21] \\
\hline Adults & Children & Reference \\
\hline$\uparrow$ & NS & Fat per kilogram [8] \\
\hline$\uparrow$ & $\uparrow$ & Fat-free mass, fat mass, and mineral [8, 9] \\
\hline$\downarrow$ & NS & Lean tissue per kilogram [8] \\
\hline$\uparrow \leftrightarrow$ & $\uparrow$ & Lean body mass [10] \\
\hline$\uparrow$ & $\uparrow$ & Extracellular water proportion [11] \\
\hline$\uparrow$ & NS & Blood volume [12] \\
\hline$\uparrow$ & NS & Cardiac output [13] \\
\hline$\leftrightarrow$ & NS & Hepatic blood flow [14] \\
\hline$\leftrightarrow$ & NS & Oral absorption [15] \\
\hline$\downarrow \uparrow$ & NS & Effect of NAFLD on hepatic metabolism [16] \\
\hline NS & $\uparrow$ & Xanthine oxidase activity [17] \\
\hline NS & $\leftrightarrow$ & CYP1 A2 activity [17] \\
\hline$\uparrow \leftrightarrow ~$ & NS & Glomerular filtration rate [18, 19] \\
\hline$\uparrow$ & NS & Renal blood flow [20, 21] \\
\hline NAFLD: non-alcoholic fatty liver disease; NS: not studied; $\uparrow:$ increased; $\downarrow:$ decreased; $\leftrightarrow:$ \\
unchanged.
\end{tabular}

articles beyond those found in PubMed. One conference abstract describing vancomycin PK in obese children was not included because insufficient study detail was provided. Drugs studied in obese children included cefazolin, tobramycin, gentamicin, and vancomycin, see Table 2 .
Cefazolin and tobramycin were studied prospectively in a study of five obese children 2-9 years-of-age (BMI > 95 percentile), and serum PK results were compared with previous results from a study of six non-obese children of similar ages [30]. The dosing weight for obese participants in this study was obtained by calculating the mean of TBW and IBW, whereas non-obese participants were dosed based on TBW. Participants in both cohorts received a single $25 \mathrm{mg} / \mathrm{kg}$ dose of cefazolin by 30-minute intravenous (IV) infusion. Ten minutes after completion of the cefazolin infusion, tobramycin was infused over 30 minutes as a single $2 \mathrm{mg} / \mathrm{kg}$ dose. Cefazolin steady-state volume of distribution (Vss) and CL normalized by TBW and protein binding were not significantly different between obese and non-obese children. Tobramycin CL normalized by TBW was not significantly different between obese and non-obese children, but Vss normalized by TBW was significantly lower in obese children compared with nonobese children $(\mathrm{p}<0.05)$.

Gentamicin was studied in a retrospective cohort study in 25 obese and 25 non-obese children with a mean \pm standard deviation age of $9.9 \pm 3.9$ years and obese children's BMI percentile of $98 \pm 1.3$ [31]. Obese children received significantly lower TBW-normalized doses relative to their non-obese peers (mean 1.86 vs $2.25 \mathrm{mg} / \mathrm{kg}$ TBW, p < 0.01), had significantly higher peak concentrations $(8.17 \pm 2.02$ vs $7.06 \pm 1.52 \mu \mathrm{g} /$ $\mathrm{mL}, \mathrm{p}<0.05)$, similar trough concentrations $(0.95 \pm 0.58$ vs $0.74 \pm 0.24 \mu \mathrm{g} / \mathrm{mL}, \mathrm{p}=0.11)$, and decreased weight-normalized V $(0.20 \pm 0.05$ vs $0.28 \pm 0.07 \mathrm{~L} / \mathrm{kg}$ TBW, $\mathrm{p}<0.01)$.

Two retrospective studies evaluated the PK of vancomycin in obese children. The first study included 70 obese and overweight children aged 2 to $<18$ years of age and mean \pm standard deviation TBW $43.4 \pm 30.4 \mathrm{~kg}$ receiving vancomycin [32]. Dose (16.6 vs

\begin{tabular}{|c|c|c|c|c|c|c|c|}
\hline Cefazolin [30] & $25 \mathrm{mg} / \mathrm{kg}$ & $\begin{array}{l}\text { Average of } \\
\text { TBW and IBW }\end{array}$ & $\mathrm{P}, \mathrm{SD}, \mathrm{I}$ & $5 \mathrm{O}, 6 \mathrm{~N}$ & $\begin{array}{l}\text { Median (range) } \\
\text { O: } 8.3(1.8-9.3)\end{array}$ & $\begin{array}{l}\text { Degree of } \\
\text { obesity* [mean } \\
\text { (StdDev)] } \\
\text { O: } 63 \%(18)\end{array}$ & $\begin{array}{l}\mathrm{Vss} / \mathrm{TBW} \leftrightarrow \\
\mathrm{CL} / \mathrm{TBW} \leftrightarrow\end{array}$ \\
\hline Gentamicin [31] & $\mathrm{O}<\mathrm{N}$ & NA & $\begin{array}{l}\mathrm{R}, \mathrm{Cmax}_{\mathrm{ss}}, \\
\mathrm{Cmin}_{\mathrm{ss}}\end{array}$ & $25 \mathrm{O}, 25 \mathrm{~N}$ & $\begin{array}{l}\text { Mean (SD) } \\
\text { O/N: } 9.9(3.9)\end{array}$ & O: BMI 98\%ile & $\begin{array}{l}\mathrm{V} / \mathrm{TBW} \downarrow \\
\mathrm{Cmax}_{\mathrm{ss}} \downarrow \\
\mathrm{Ke}, \mathrm{t} 1 / 2, \\
\mathrm{Cmin}_{\mathrm{ss}} \leftrightarrow \\
\end{array}$ \\
\hline Vancomycin [33] & $\mathrm{O}<\mathrm{N}$ & NA & $\begin{array}{l}\mathrm{R}, \mathrm{Cmax}_{\mathrm{ss}}, \\
\mathrm{Cmin}_{\mathrm{ss}}\end{array}$ & $24 \mathrm{O}, 24 \mathrm{~N}$ & $\begin{array}{l}\text { Mean (SD) } \\
\text { O: } 6.8(4.3)\end{array}$ & O: BMI 97\%ile & $\mathrm{t} 1 / 2, \mathrm{Ct} \leftrightarrow$ \\
\hline
\end{tabular}


$17.2 \mathrm{mg} / \mathrm{kg}$ TBW, $\mathrm{p}=0.295$ ) and dosing frequency were not significantly different between the obese/overweight cohort and their non-obese peers. In spite of similar TBW-normalized doses, mean steady-state trough concentrations were higher in overweight or obese children compared with normal-weight children (9.6 vs $7.4 \mu \mathrm{g} / \mathrm{mL}, \mathrm{p}=0.03$ ), but this difference was not clinically significant as both mean troughs were within the target range defined by the study $(5-15 \mu \mathrm{g} / \mathrm{mL})$. Neither the proportion of therapeutic troughs $(63.0 \%$ vs $61.4 \%, \mathrm{p}=0.825)$ nor the frequency of nephrotoxicity $(8.5 \%$ vs $3.0 \%, p=0.093)$ or red-man syndrome $(45.7 \%$ vs $50.6 \%, \mathrm{p}=0.493)$ differed between obese/overweight and non-obese children, respectively. The other retrospective study of IV vancomycin in 24 obese and 24 non-obese children (mean \pm standard deviation $6.8 \pm 4.31$ years of age and obese BMI percentile $97.3 \pm 1.49$ ) showed that obese children received lower TBW-normalized doses (not clinically significant, $14.1 \mathrm{vs} 14.9 \mathrm{mg} / \mathrm{kg}$ TBW/dose, $\mathrm{p}=0.03$ ) and higher, albeit not statistically significant, steadystate serum trough vancomycin concentrations (6.9 vs $4.8 \mathrm{ug}$ / $\mathrm{mL}, \mathrm{p}=0.052$ ) [33]

\section{Discussion}

This review highlights the lack of PK and dosing information for the most commonly used drugs (antibiotics) in obese children. The lack of PK data is not only substantial overall but even more pronounced for orally administered drugs and those undergoing extensive liver biotransformation. For the four antibiotics studied thus far, no clinically relevant differences in drug distribution justify dosing modifications, suggesting that 1 ) there are truly no differences; 2) larger studies need to be conducted to observe a difference; or 3) children at the extreme of the obesity spectrum need to be included in clinical trials.

Obesity results in numerous changes to physiology and body composition that may affect drug disposition and dosing, see Table 1. Volume of distribution (V) and clearance (CL), the primary determinants of drug dosing, may be affected differently depending on the drug's physicochemical properties and routes of metabolism and elimination [34, 35]. $\mathrm{V}$ may be affected by distribution of drug into tissues, which is determined by drug properties such as lipophilicity, as well as physiologic characteristics such as body composition, organ blood flows, and drug protein- and tissue-binding. Changes in body composition and organ blood flows have been documented in obese adults and children, see Table 1. $\mathrm{CL}$ in obese individuals can be affected by weight-related changes in renal function (glomerular filtration rate and renal blood flow) [19, 36] or changes in the activity of drug-metabolizing enzymes [17]. For example, xanthine oxidase and $\mathrm{N}$-acetyltransferase 2-mediated metabolism of caffeine was elevated in obese children compared with non-obese children $(\mathrm{p}<0.05)[17]$.

In the absence of data supporting dosing, body size measures are often chosen to dose drugs in obese children on the basis of drug physicochemical characteristics, e.g. lipophilicity, protein-binding, drug distribution profiles, and drug elimination pathways. Traditionally, non-obese children are dosed per kg of TBW, but other body size measures, e.g. IBW, LBW, body surface area; may better correlate with $\mathrm{V}$ and $\mathrm{CL}$ in obese children and achieve more appropriate exposure.

Due to the expected affinity of lipophilic drugs to adipose tissue, it is hypothesized that lipophilic drugs will have increased $\mathrm{V}$ in obese patients, resulting in the need for a higher initial dose. Conversely, hydrophilic drugs are expected to remain in the intra-vascular space, bind less to adipose tissue, and thus lower $\mathrm{V}$, placing children at risk for overdose. Unfortunately, the relationship between a drug's lipophilicity and its distribution to adipose tissue is not always consistent and predictable, especially for highly lipophilic drugs. A study of five lipophilic $\beta$-blockers found greater binding to lean tissue than adipose tissue [37]. Tobramycin and gentamicin are highly and moderately lipophilic (-LogP $=5.8$ and 3.1, respectively), but both distribute primarily in extracellular fluid, not adipose, see Table 3 . The distribution is consistent with the finding of decreased Vss/kg TBW in obese children observed for both tobramycin and gentamicin. Vss/kg TBW was also decreased $(0.29 \pm 0.13$ vs $0.33 \pm 0.11 \mathrm{~L} / \mathrm{kg}, \mathrm{p} \leq 0.05)$ in a large prospective study of obese and non-obese adults who received tobramycin or gentamicin [38]. Conversely, cefazolin, a drug with low lipophilicity $(-\log P=0.6)$, widely distributed to tissues, see Table 3 . Based on lipophilicity alone, it would be reasonable to hypothesize that $\mathrm{V} / \mathrm{kg}$ TBW would be decreased in obese individuals, requiring a lower initial dose per $\mathrm{kg}$ of TBW. Lower cefazolin $\mathrm{V} / \mathrm{kg}$ TBW was seen in obese adults [39] compared with nonobese adults [40]. However, in the five obese children in the study described above, cefazolin V/kg TBW was unchanged compared with their non-obese peers. It is unclear why obesity affects $\mathrm{V}$ in adults but not children, but it could be related to a small sample size in the paediatric study that prevented identification of differences. Vancomycin has moderate lipophilicity $(-\log \mathrm{P}=3.1)$ and is distributed to total body water and tissues, see Table 3. Similar to cefazolin, unchanged vancomycin $\mathrm{V} / \mathrm{kg}$ TBW in children is inconsistent with reports of decreased $\mathrm{V} / \mathrm{kg}$ TBW in obese adults $[41,42]$. Clearly, for the drugs included in this report which were evaluated in small cohorts of children, drug lipophilicity is not predictive of drug distribution. The combination of degree of solubility and extent of metabolism
Table 3: Properties of drugs used in pharmacokinetic studies in obese children [30-33]

\begin{tabular}{|l|l|l|l|l|}
\hline Drug & Lipophilicity & Distribution & $\begin{array}{l}\text { Protein } \\
\text { binding }\end{array}$ & Elimination \\
\hline Cefazolin [30] & Low & Widely, to most tissues & $80 \%$ & Renal (60-80\%) \\
\hline Tobramycin [30] & High & $\begin{array}{l}\text { Mainly extracellular } \\
\text { fluid }\end{array}$ & $0-30 \%$ & $\begin{array}{l}\text { Renal (60-85\%), } \\
\text { mainly excretion, } \\
\text { some secretion }\end{array}$ \\
\hline Gentamicin [31] & Intermediate & $\begin{array}{l}\text { Mainly extracellular } \\
\text { fluid }\end{array}$ & $0-30 \%$ & $\begin{array}{l}\text { Renal (70-100\%), } \\
\text { mainly excretion, } \\
\text { some secretion }\end{array}$ \\
\hline $\begin{array}{l}\text { Vancomycin } \\
{[32,33]}\end{array}$ & Intermediate & $\begin{array}{l}\text { Total body water and } \\
\text { other tissues }\end{array}$ & $30-55 \%$ & Renal (40-100\%) \\
\hline
\end{tabular}


(Biopharmaceutics Drug Disposition Classification System class) also did not distinguish the different distribution profiles of the drugs included in this report, as all four are highly soluble and poorly metabolized.

Studies have investigated the effect of obesity on drug binding to blood proteins or lipids. Serum albumin and total protein levels are unchanged in obesity, while the effect of obesity on alpha-1-acid glycoprotein levels is inconclusive [43-45]. However, drug binding is influenced by more than absolute concentrations of serum proteins. Free fatty acid and triglyceride levels may affect a drug's affinity for serum proteins, and free fatty acids and triglycerides are often increased in obesity. In vitro studies on the effects of free fatty acid levels on protein-binding found increased albumin binding of three out of six acidic antibiotics when the ratio of free fatty acid concentration to protein concentration was $>2$; binding of three basic and neutral antibiotics was unchanged regardless of free fatty acid concentration [46].

Drug CL depends on clearance organ size and function. The liver and kidney are lean organs, and LBW is increased in obesity (though less than adipose as a fraction of excess weight). A study of 21 participants with normal liver and renal function found that liver volume was not a significant predictor of antipyrine clearance, while kidney volume appeared to mediate the association between LBW and creatinine clearance [47]. CL can also be affected by obesityrelated changes in drug-metabolizing enzyme activity or renal function. Drugs eliminated via glomerular filtration or renal tubular-mediated processes, or that are metabolized by uridine diphosphate glucuronosyltransferase, xanthine oxidase, N-acetyltransferase, and cytochrome P450 (CYP) 2E1, have increased $\mathrm{CL}$ reported in obese adults; drugs metabolized by CYP3A4 have decreased CL [48]. Animal studies in obese mice suggest that increased kidney size and glomerular hypertrophy may result in increased glomerular filtration rate [49], and that lipid accumulation in the liver and induction of pro-inflammatory cytokines are possible mechanisms for alteration of drug-metabolizing enzyme expression [50, 51]. Non-alcoholic fatty liver disease is associated with obesity, and clinical studies indicate that CYP2E1 activity is increased with this condition [52, 53]. Other CYPs have not been evaluated in clinical studies of patients with non-alcoholic fatty liver disease; however, an in vitro human liver microsome study of drug-metabolizing enzyme activity found that progression of non-alcoholic fatty liver disease was associated with decreasing activity of CYP1A2 and CYP2C19 and increasing activity of CYP2A6 and CYP2C9 [16].

No CL changes were observed in obese children in the studies included in this review. For cefazolin, this is inconsistent with data in obese adults. Cefazolin CL (4.2 vs $3.9 \mathrm{~L} / \mathrm{h}$ ) and V (13.0 vs $12.3 \mathrm{~L})$ estimates in obese adults [39] were similar to non-obese adults [40]; thus $\mathrm{CL} / \mathrm{kg}$ TBW and $\mathrm{V} / \mathrm{kg}$ TBW would be likely reduced in obese adults. As was the case in the studies of obese children, aminoglycoside and vancomycin $\mathrm{CL} / \mathrm{kg}$ TBW was found to be unchanged in obese adults [38, 41, 42]. One limitation to the evaluation of vancomycin PK in obese children was the large fraction of children in both groups with undetectable trough concentrations [33].

In spite of limited PK data in obese children, dosing recommendations have been suggested. The cefazolin study recommended the use of TBW for initial dosing. The tobramycin study recommended dosing by ABW in obese children, consistent with adult obesity dosing [54]. Unlike the tobramycin study, the gentamicin study recommended dose reduction as opposed to using ABW. Both methods would result in a lower absolute dose administered. Due to the lack of observed obesity effect on vancomycin PK, the two studies recommended the use of TBW for dosing of obese children, consistent with dosing recommendations in obese adults [55].

Prospective studies of antimicrobial PK in obese children are needed to provide information on optimal dosing to clinicians. Future studies should consider drug physicochemical properties in addition to elimination pathways when developing dosing regimens. As stated above, $\mathrm{V} / \mathrm{kg}$ TBW of moderate to highly lipophilic drugs are more likely to be affected by obesity [56]; effects on CL/kg TBW may be dependent on pathway(s) of elimination. The use of probe drugs for specific elimination pathways would enable extrapolation of results for other substrates of that pathway. The use of modelling and simulation approaches such as physiologically based PK, which incorporates both drug and physiological information, may help to provide mechanistic insights and inform study designs in this special population [57]. As there are no reliable predictors of obesity effects on PK in children, future studies of antibiotics in obese children should be prioritized based on clinical importance and frequency of use.

\section{Conclusion}

Optimization of antimicrobial dosing in obese children is at an early stage. Most classes of antimicrobial agents have yet to be studied in this population. Physicochemical properties alone do not reliably predict drug disposition, and traditional body size measures (actual body weight) used for dosing of drugs in obese children do not account for potential changes in CL mechanisms such as drug-metabolizing enzyme activity and renal function. The few studies done to date have not shown clinically relevant differences in PK or dosing in obese children relative to their non-obese peers. Future studies should consider drug physicochemical properties, known physiologic changes in obesity, as well as drug elimination pathways.

\section{Key message}

Antibiotics are commonly prescribed to obese children. Obesity-induced changes in antibiotic disposition can lead to toxicity or therapeutic failure. Antimicrobial studies to optimize dosing in obese children are desperately needed.

\section{Acknowledgements}

This review was conducted on behalf of the Best Pharmaceuticals for Children Act - Pediatric Trials Network. 


\section{Sources of support}

This work was funded under NICHD contract HHSN 27520 10000031 for the Pediatric Trials Network. MR Sampson is supported by US National Institute of General Medical Sciences 1T32GM86330-1A1. M Cohen-Wolkowiez is supported by US National Institute for Child Health and Human Development 1K23HD064814-01 for his work in paediatric clinical pharmacology and from industry for neonatal and paediatric drug development (www.dcri.duke.edu/research/coi.jsp). DK Benjamin Jr is supported by the US government (1R01HD05795602, 1R01FD003519-01, 1U10-HD45962-06, 1K24HD058735-01, contract HHSN267200700051C), Thrasher Research Foundation, and industry (www.dcri.duke.edu/research/coi.jsp). E Capparelli is supported by US National Institute of Allergy and Infectious Disease U01AI68632 and 1U54HD071600-01. KM Watt is supported by US National Institute for Child Health and Human Development 5T32HD043029-09 and the Thrasher Foundation (www.dcri.duke.edu/research/coi.jsp).

\section{Competing interests: None.}

Provenance and peer review: Not commissioned; externally peer reviewed.

\section{Authors}

Mario R Sampson ${ }^{1,2}$, PharmD

Michael Cohen-Wolkowiez ${ }^{1,3}, \mathrm{MD}, \mathrm{PhD}$

Professor Daniel Kelly Benjamin $\mathrm{Jr}^{1,3}$, MD, MPH, PhD

Edmund V Capparelli ${ }^{4}$, PharmD

Kevin M Watt ${ }^{1,3}$, MD

${ }^{1}$ Duke Clinical Research Institute, Durham, NC, USA

${ }^{2}$ UNC Eshelman School of Pharmacy, University of North Carolina, Chapel Hill, NC, USA

${ }^{3}$ Department of Pediatrics, Duke University Medical Center, Durham, NC, USA

${ }^{4}$ Department of Pediatrics, School of Medicine and Department of Clinical Pharmacy, Skaggs School of Pharmacy, University of California-San Diego, La Jolla, CA, USA

\section{References}

1. World Health Organization. Training course on child growth assessment. WHO child growth standards. Investigating causes of undernutrition and of overweight [homepage on the Internet]. 2012 [cited 2013 May 24]. Available from: http://www.who.int/childgrowth/training/jobaid_investigating_causes.pdf

2. World Health Organization. Growth reference data for 5-19 years [homepage on the Internet]. 2013 [cited 2013 May 24]. Available from: http://www.who. int/growthref/en/

3. Centers for Disease Control and Prevention. Basics about childhood obesity [homepage on the Internet]. [updated 2012 Apr 27; cited 2013 May 24]. Available from: http://www.cdc.gov/obesity/childhood/basics.html

4. de Onis M, Blossner M, Borghi E. Global prevalence and trends of overweight and obesity among preschool children. Am J Clin Nutr. 2010;92(5):1257-64.

5. Ogden CL, Carroll MD, Curtin LR, Lamb MM, Flegal KM. Prevalence of high body mass index in US children and adolescents, 2007-2008. JAMA. 2010;303(3):242-9.

6. Must A, Phillips SM, Naumova EN. Occurrence and timing of childhood overweight and mortality: findings from the Third Harvard Growth Study. J Pediatr. 2012;160(5):743-50.

7. Pinhas-Hamiel O, Dolan LM, Daniels SR, et al. Increased incidence of noninsulin-dependent diabetes mellitus among adolescents. J Pediatr. 1996;128 (5 Pt 1):608-15.
8. Forbes GB Welle SL. Lean body mass in obesity. Int J Obes. 1983;7(2 99-107.

9. Wells JC, Fewtrell MS, Williams JE, et al. Body composition in normal weight, overweight and obese children: matched case-control analyses of total and regional tissue masses, and body composition trends in relation to relative weight. Int J Obes (Lond). 2006;30(10):1506-13.

10. Forbes GB. Lean body mass and fat in obese children. Pediatrics. 1964;34: 308-14.

11. Chumlea WC, Schubert CM, Sun SS, et al. A review of body water status and the effects of age and body fatness in children and adults. J Nutr Health Aging. 2007;11(2):111-8.

12. Alexander JK, Dennis EW, Smith WG, et al. Blood volume, cardiac output, and distribution of systemic blood flow in extreme obesity. Cardiovasc Res Cent Bull. 1962;1:39-44.

13. Collis T, Devereux RB, Roman MJ, et al. Relations of stroke volume and cardiac output to body composition: the strong heart study. Circulation. 2001; 103(6):820-5.

14. Messerli FH, Sundgaard-Riise K, Reisin E, et al. Disparate cardiovascular effects of obesity and arterial hypertension. Am J Med. 1983;74(5):808-12.

15. Kees MG, Weber S, Kees F, Horbach T. Pharmacokinetics of moxifloxacin in plasma and tissue of morbidly obese patients. J Antimicrob Chemother. 2011;66(10):2330-5.

16. Fisher CD, Lickteig AJ, Augustine LM, et al. Hepatic cytochrome P450 enzyme alterations in humans with progressive stages of nonalcoholic fatty liver disease. Drug Metab Dispos. 2009;37(10):2087-94.

17. Chiney MS, Schwarzenberg SJ, Johnson LA. Altered xanthine oxidase and N-acetyltransferase activity in obese children. $\mathrm{Br} \mathrm{J}$ Clin Pharmacol. 2011;72(1):109-15.

18. Pai MP, Norenberg JP, Anderson T, et al. Influence of morbid obesity on the single-dose pharmacokinetics of daptomycin. Antimicrob Agents Chemother. 2007;51(8):2741-7.

19. Stokholm KH, Brochner-Mortensen J, Hoilund-Carlsen PF. Increased glomerular filtration rate and adrenocortical function in obese women. Int J Obes. 1980;4(1):57-63.

20. Reisin E, Messerli FG, Ventura HO, Frohlich ED. Renal haemodynamic studies in obesity hypertension. J Hypertens. 1987;5(4):397-400.

21. Porter LE Hollenberg NK. Obesity, salt intake, and renal perfusion in healthy humans. Hypertension. 1998;32(1):144-8.

22. Srinivasan V, Nadkarni VM, Helfaer MA, Carey SM, Berg RA. Childhood obesity and survival after in-hospital pediatric cardiopulmonary resuscitation. Pediatrics. 2010;125(3):e481-8.

23. Griggs JJ, Mangu PB, Anderson H, et al. Appropriate chemotherapy dosing for obese adult patients with cancer: American Society of Clinical Oncology clinical practice guideline. J Clin Oncol. 2012;30(13):1553-61.

24. Westat. Frequency of medication usage in the pediatric population. detailed report: Part 1 of 2. Rockville, MD: Eunice Kennedy Shriver National Institute of Child Health and Human Development; 2005. Contract GS-23F-8144H; task order HHSN275200403388C

25. Jedrychowski W, Maugeri U, Flak E, Mroz E, Bianchi I. Predisposition to acute respiratory infections among overweight preadolescent children: an epidemiologic study in Poland. Public Health. 1998;112(3):189-95.

26. Keys A, Fidanza F, Karvonen MJ, Kimura N, Taylor HL. Indices of relative weight and obesity. J Chronic Dis. 1972;25(6):329-43.

27. Build and Blood Pressure Study. Society of Actuaries. 1959, New York: Peter Mallon.

28. Morgan DJ, Bray KM. Lean body mass as a predictor of drug dosage. Implications for drug therapy. Clin Pharmacokinet. 1994;26(4):292-307.

29. Bauer LA, Edwards WA, Dellinger EP, Simonowitz DA. Influence of weight on aminoglycoside pharmacokinetics in normal weight and morbidly obese patients. Eur J Clin Pharmacol. 1983;24(5):643-7.

30. Koshida R, Nakashima E, Taniguchi N, et al. Prediction of the distribution vol- 
umes of cefazolin and tobramycin in obese children based on physiological pharmacokinetic concepts. Pharm Res. 1989;6(6):486-91.

31. Choi JJ, Moffett BS, McDade EJ, Palazzi DL. Altered gentamicin serum concentrations in obese pediatric patients. Pediatr Infect Dis J. 2011;30(4):347-9.

32. Miller M, Miller JL, Hagemann TM, et al. Vancomycin dosage in overweight and obese children. Am J Health Syst Pharm. 2011;68(21):2062-8.

33. Moffett BS, Kim S, Edwards MS. Vancomycin dosing in obese pediatric patients. Clin Pediatr (Phila). 2011;50(5):442-6.

34. Chen M, Nafziger AN, Drusano GL, Ma L, Bertino JS, Jr. Comparative pharmacokinetics and pharmacodynamic target attainment of ertapenem in normalweight, obese, and extremely obese adults. Antimicrob Agents Chemother. 2006;50(4):1222-7.

35. Dvorchik BH Damphousse D. The pharmacokinetics of daptomycin in moderately obese, morbidly obese, and matched nonobese subjects. J Clin Pharmacol. 2005;45(1):48-56.

36. Bosma RJ, Krikken JA, Homan van der Heide JJ, de Jong PE, Navis GJ. Obesity and renal hemodynamics. Contrib Nephrol. 2006;151:184-202.

37. Cheymol G, Poirier JM, Carrupt PA, et al. Pharmacokinetics of betaadrenoceptor blockers in obese and normal volunteers. Br J Clin Pharmacol. 1997;43(6):563-70

38. Traynor AM, Nafziger AN, Bertino JS, Jr. Aminoglycoside dosing weight correction factors for patients of various body sizes. Antimicrob Agents Chemother. 1995;39(2):545-8.

39. van Kralingen S, Taks M, Diepstraten J, et al. Pharmacokinetics and protein binding of cefazolin in morbidly obese patients. Eur J Clin Pharmacol. 2011;67(10):985-92.

40. Lanao JM, Vicente MT, Dominguez-Gil A. Pharmacokinetics of cefazolin administered as a new drug delivery system in healthy volunteers. Biopharm Drug Dispos. 1988;9(4):377-88.

41. Blouin RA, Bauer LA, Miller DD, Record KE, Griffen WO, Jr. Vancomycin pharmacokinetics in normal and morbidly obese subjects. Antimicrob Agents Chemother. 1982;21(4):575-80

42. Bauer LA, Black DJ, Lill JS. Vancomycin dosing in morbidly obese patients. Eur J Clin Pharmacol. 1998;54(8):621-5.

43. Abernethy DR Greenblatt DJ. Phenytoin disposition in obesity. Determination of loading dose. Arch Neurol. 1985;42(5):468-71.

44. Benedek IH, Fiske WD, 3rd, Griffen WO, et al. Serum alpha 1-acid glycoprotein and the binding of drugs in obesity. Br J Clin Pharmacol. 1983;16(6): $751-4$.
45. Cheymol G, Poirier JM, Barre J, Pradalier A, Dry J. Comparative pharmacokinetics of intravenous propranolol in obese and normal volunteers. J Clin Pharmacol. 1987;27(11):874-9

46. Suh B, Craig WA, England AC, Elliott RL. Effect of free fatty acids on protein binding of antimicrobial agents. J Infect Dis. 1981;143(4):609-16.

47. Nawaratne S, Brien JE, Seeman E, et al. Relationships among liver and kidney volumes, lean body mass and drug clearance. Br J Clin Pharmacol. 1998;46(5):447-52.

48. Brill MJ, Diepstraten J, van Rongen A, et al. Impact of obesity on drug metabolism and elimination in adults and children. Clin Pharmacokinet. 2012;51(5):277-304.

49. Griffin KA, Kramer H, Bidani AK. Adverse renal consequences of obesity. Am J Physiol Renal Physiol. 2008;294(4):F685-96.

50. Ghose R, Omoluabi O, Gandhi A, et al. Role of high-fat diet in regulation of gene expression of drug metabolizing enzymes and transporters. Life Sci. 2011;89(1-2):57-64

51. Yoshinari K, Takagi S, Yoshimasa T, Sugatani J, Miwa M. Hepatic CYP3 A expression is attenuated in obese mice fed a high-fat diet. Pharm Res. 2006; 23(6): 1188-200

52. Emery MG, Fisher JM, Chien JY, et al. CYP2E1 activity before and after weight loss in morbidly obese subjects with nonalcoholic fatty liver disease. Hepatology. 2003;38(2):428-35.

53. Chalasani N, Gorski JC, Asghar MS, et al. Hepatic cytochrome P450 2E1 activity in nondiabetic patients with nonalcoholic steatohepatitis. Hepatology. 2003;37(3):544-50.

54. Pai MP Bearden DT. Antimicrobial dosing considerations in obese adult patients. Pharmacotherapy. 2007;27(8):1081-91.

55. Rybak M, Lomaestro B, Rotschafer JC, et al. Therapeutic monitoring of vancomycin in adult patients: a consensus review of the American Society of Health-System Pharmacists, the Infectious Diseases Society of America, and the Society of Infectious Diseases Pharmacists. Am J Health Syst Pharm. 2009;66(1):82-98.

56. Jain R, Chung SM, Jain L, et al. Implications of obesity for drug therapy: limitations and challenges. Clin Pharmacol Ther. 2011;90(1):77-89.

57. Ghobadi C, Johnson TN, Aarabi M, et al. Application of a systems approach to the bottom-up assessment of pharmacokinetics in obese patients: expected variations in clearance. Clin Pharmacokinet. 2011;50(12):809-22.

DOI: $10.5639 /$ gabij.2013.0202.025

Copyright (c) 2013 Pro Pharma Communications International 